\title{
CAMA
}

Centre for Applied Macroeconomic Analysis

\section{Risk Sharing in a World Economy with Uncertainty Shocks}

\section{CAMA Working Paper 44/2015 November 2015}

\section{Robert Kollmann}

ECARES, Université Libre de Bruxelles

CEPR and

Centre for Applied Macroeconomic Analysis (CAMA), ANU

\section{Abstract}

This paper analyzes the effects of output volatility shocks and of risk appetite shocks on the dynamics of consumption, trade flows and the real exchange rate, in a two-country world with recursive preferences and complete financial markets. When the risk aversion coefficient exceeds the inverse of the intertemporal substitution elasticity, then an exogenous rise in a country's output volatility triggers a wealth transfer to that country, in equilibrium; this raises its consumption, lowers its trade balance and appreciates its real exchange rate. The effects of risk appetite shocks resemble those of volatility shocks. In a recursive preferences-complete markets framework, volatility and risk appetite shocks account for a noticeable share of the fluctuations of net exports, net foreign assets and the real exchange rate. These shocks help to explain the high empirical volatility of the real exchange rate and the disconnect between relative consumption growth and the real exchange rate. 


\section{Keywords}

External balance, exchange rate, volatility, risk appetite, consumption-real exchange rate anomaly.

\section{JEL Classification}

F31, F32, F36, F41, F43

\section{Address for correspondence:}

(E) cama.admin@anu.edu.au

The Centre for Applied Macroeconomic Analysis in the Crawford School of Public Policy has been established to build strong links between professional macroeconomists. It provides a forum for quality macroeconomic research and discussion of policy issues between academia, government and the private sector.

The Crawford School of Public Policy is the Australian National University's public policy school, serving and influencing Australia, Asia and the Pacific through advanced policy research, graduate and executive education, and policy impact. 


\title{
Risk Sharing in a World Economy with Uncertainty Shocks
}

\author{
Robert Kollmann (*) \\ ECARES, Université Libre de Bruxelles and CEPR \\ Centre for Applied Macroeconomic Analysis (CAMA)
}

First draft: July 5, 2014

This draft: November 17, 2015

\begin{abstract}
This paper analyzes the effects of output volatility shocks and of risk appetite shocks on the dynamics of consumption, trade flows and the real exchange rate, in a two-country world with recursive preferences and complete financial markets. When the risk aversion coefficient exceeds the inverse of the intertemporal substitution elasticity, then an exogenous rise in a country's output volatility triggers a wealth transfer to that country, in equilibrium; this raises its consumption, lowers its trade balance and appreciates its real exchange rate. The effects of risk appetite shocks resemble those of volatility shocks. In a recursive preferences-complete markets framework, volatility and risk appetite shocks account for a noticeable share of the fluctuations of net exports, net foreign assets and the real exchange rate. These shocks help to explain the high empirical volatility of the real exchange rate and the disconnect between relative consumption growth and the real exchange rate.
\end{abstract}

Key words: external balance, exchange rate, volatility, risk appetite, consumption-real exchange rate anomaly.

JEL codes: F31, F32, F36, F41, F43.

$\left({ }^{*}\right)$ Contact address: European Centre for Advanced Research in Economics and Statistics (ECARES), CP 114, Université Libre de Bruxelles, 50 Av. Franklin Roosevelt, B-1050 Brussels, Belgium; robert_kollmann@yahoo.com www.robertkollmann.com. I am also affiliated with the Globalization and Monetary Policy Institute (Federal Reserve Bank of Dallas) and the Centre for Applied Macroeconomic Analysis (CAMA) at Australian National University. I thank David Backus, Chase Coleman, Axelle Ferriere, Johannes Pfeifer and Eric Swanson for useful discussions.

The research leading to these results has received funding from the European Community's Seventh Framework Programme (FP7/2007-2013) under grant agreement no. 612796, Project MACFINROBODS ('Integrated Macro-Financial Modelling for Robust Policy Design'). 


\section{Introduction}

The turmoil triggered by the recent global financial crisis has stimulated much research on the macroeconomic effects of economic volatility (uncertainty) shocks. Most theoretical macro models with volatility shocks assume closed economies (see survey by Bloom (2014)). This paper provides simple analytics and simulation results for the effect of output volatility shocks in open economies. A two-country, two-goods endowment economy with consumption home bias and recursive preferences of the Epstein and Zin (1989) and Weil $(1989,1990)$ type is considered. Under these preferences, the coefficient of risk aversion can differ from the inverse of the intertemporal elasticity of substitution. This flexibility explains why recursive preferences are widely assumed in the finance literature-however, the international macroeconomics literature has only recently begun to consider models with recursive preferences (see below).

The baseline model here assumes complete financial markets, so that consumption risk is efficiently shared across countries. The paper shows that, under recursive preferences, output volatility shocks can account for a noticeable share of the fluctuations of net exports, net foreign assets and the real exchange rate. Volatility shocks help to explain the observed high volatility of the real exchange rate and the disconnect between relative consumption growth and the real exchange rate.

With complete markets, the ratio of the Home intertemporal marginal rate of substitution (IMRS) to the Foreign IMRS is equated to the growth factor of the real exchange rate, in equilibrium. Under standard time-separable preferences, this condition entails that consumption and the real exchange rate solely depend on contemporaneous domestic and foreign output-in an endowment economy, this static equilibrium condition implies that consumption and the real exchange rate are not affected by uncertainty about future output. ${ }^{1}$ A powerful channel for the transmission of output volatility shocks emerges when agents have recursive preferences. If the coefficient of risk aversion (CRA) differs from the inverse of the intertemporal elasticity of substitution (IES), then a household's IMRS depends on her future life-time utility. As volatility shocks affect life-time utility, these shocks impact the IMRS when CRA $\neq 1 /$ IES, and thus

\footnotetext{
${ }^{1}$ In a production economy, uncertainty shocks may affect labor supply and the current output level, and thus influence consumption and the real exchange rate. Analysis of this mechanism is left for future research.
} 
volatility shocks affect equilibrium consumption, trade flows and the real exchange rate. Under the common assumption that CRA>1/IES (e.g. Swanson (2014)), which implies a preference for the early resolution of uncertainty over future consumption (Weil (1990)), a fall in future life-time utility raises the household's IMRS. Efficient risk sharing thus implies that an idiosyncratic rise in a country's output volatility triggers a wealth transfer from the rest of the world to that country, i.e. the country's net foreign assets increase. This raises the country's consumption and net imports, and it improves its terms of trade and appreciates its real exchange rate (due to local spending bias).

The model here can solve the widely discussed 'consumption-real exchange rate anomaly' (Obstfeld and Rogoff (2000)). Standard models predict that a rise in a country's relative output increases its relative consumption and depreciates its real exchange rate (Kollmann (1991, 1995), Backus and Smith (1993), Devereux and Kollmann (2012)). Yet, empirically, the growth rate of relative consumption and the rate of appreciation of the real exchange rate are (essentially) uncorrelated. The recursive preferences model here offers a possible solution to this puzzle. The model predicts that output volatility shocks induce positively correlated responses of a country's relative consumption growth and of the rate of appreciation of its real exchange rate. A model with simultaneous shocks to the level and the volatility of output can generate a realistic correlation between relative consumption and the real exchange rate, i.e. a correlation that is close to zero.

It is often argued informally that, like volatility shocks, changes in investors' risk appetite can be important drivers of international capital flows, and of the real exchange rate (e.g., International Monetary Fund (2013)). However, this notion has not yet been analyzed using quantitative dynamic general equilibrium models. I use the model here as a laboratory to explore the effect of exogenous shifts in agents' risk aversion. Risk aversion shocks are shown to have similar effects as volatility shocks. A rise in a country's risk aversion lowers its life-time utility-under recursive preferences and efficient risk sharing, this implies that the country receives a wealth transfer from the rest of the world, and thus the country's consumption and her NFA rise, and her real exchange rate appreciates.

The work here is related to several recent papers that study open economy macro models with recursive preferences; see, e.g., Kollmann (2009, 2015b), Colacito and 
Croce (2011, 2013), Lewis and Liu (2014), Gourio et al. (2013, 2015), Tretvoll (2013), Caporale et al. (2014) and Sauzet (2015). Those papers do not study the effect of volatility or risk aversion shocks. Backus et al. (2015) and Mumtaz and Theodoridis (2015) study the effect of volatility shocks in open economy models with recursive preferences, but the focus of these papers is different. ${ }^{2}$ Those papers do not study the effects of output volatility shocks or of risk aversion shocks.

The paper here is also complementary to research by Fogli and Perri (2014) and by Hoffmann et al. (2014) who study the effect of output volatility shocks in one-good models with time separable preferences and international financial markets that are incomplete, because just a riskless bond can be traded internationally. ${ }^{3}$ The focus of the paper here (efficient risk sharing, consumption-real exchange rate co-movements and related open economy stylized facts) is different. It shows that the effect of volatility shocks is markedly stronger in a complete markets world (with recursive preferences) than in a bonds-only setting. A bonds-only model seems restrictive as, in reality, statecontingent assets (equities, derivatives, bonds of different maturities and denominated in different currencies etc.) are widely traded internationally. ${ }^{4}$ Thus it is important to understand the effect of volatility shocks in the presence of a richer international assets menu--this is why the paper here assumes complete markets. A useful avenue for future research would be to extend the framework here by considering asset structures with partial risk sharing (e.g., structures in which only a subset of agents have access to complete markets, while other agents are financially constrained; see Kollmann (2012)).

Section 2 describes the baseline model with recursive preferences, time-varying output volatility and risk aversion shocks. Sect. 3 discusses empirical regularities about international business cycles. Sect. 4 presents simulation results and Sect. 5 concludes.

\footnotetext{
${ }^{2}$ Backus et al. (2015) explore the dynamics of Pareto weights in a two-country RBC production economy. Mumtaz and Theodoridis (2015) use a two-country New Keynesian model to study the effect of volatility shocks in the presence of nominal rigidities.

${ }^{3}$ I learnt about these papers after the bulk of the research described in this paper had been completed. Other related studies include Fernandez-Villaverde et al. (2011) and Born and Pfeifer (2014) who model the effect of foreign interest rate volatility on a small open economy; these authors too assume time-separable preferences, and a bonds-only structure.

${ }^{4}$ The recent global financial crisis has shown that foreign asset holdings can lead to large-scale international risk shifting (e.g., Kollmann et al. (2011)).
} 


\section{A two-country model}

\subsection{Preferences, endowments, risk sharing}

A world with two countries, Home $(H)$ and Foreign $(F)$ is assumed. The two countries have symmetric structures. Each country is inhabited by a representative infinitely-lived household. All agents observe current and past realizations of all variables (full information). At date $t$, country $i=H, F$ receives an exogenous endowment of $Y_{i, t}$ units of a perishable tradable output good $i$. The country $i$ household combines local and imported output into aggregate consumption, using the technology:

$$
C_{i, t}=\left[\alpha^{1 / \phi}\left(y_{i, t}^{i}\right)^{(\phi-1) / \phi}+(1-\alpha)^{1 / \phi}\left(y_{i, t}^{j}\right)^{(\phi-1) / \phi}\right]^{\phi(\phi-1)}, \quad j \neq i,
$$

where $y_{i, t}^{j}$ is the amount of input $j$ used by country $i ; \phi>0$ is the substitution elasticity between inputs. There is local spending bias: $0.5<\alpha<1$. At $t$, country $i$ 's consumption price index is:

$$
P_{i, t}=\left[\alpha\left(p_{i, t}\right)^{1-\phi}+(1-\alpha)\left(p_{j, t}\right)^{1-\phi}\right]^{1 /(1-\phi)}, j \neq i
$$

where $p_{j, t}$ is the price of good $j$. The Home terms of trade and real exchange rate are defined as

$$
q_{t} \equiv p_{H, t} / p_{F, t} \text { and } R E R_{t} \equiv P_{H, t} / P_{F, t} \text {, }
$$

respectively, i.e. a rise in $R E R$ represents an appreciation of the Home real exchange rate. Input demands are:

$$
y_{i, t}^{i}=\alpha\left(p_{i, t} / P_{i, t}\right)^{-\phi} C_{i, t}, \quad y_{i, t}^{j}=(1-\alpha)\left(p_{j, t} / P_{i, t}\right)^{-\phi} C_{i, t} \text { for } j \neq i .
$$

Market clearing requires $y_{H, t}^{i}+y_{F, t}^{i}=Y_{i, t}$ for $i=H, F$.

The country $i$ household has a recursive intertemporal utility function inspired by Epstein and Zin (1989) and Weil (1989, 1990):

$$
U_{i, t}=\left\{\left(1-\beta_{i, t}\right) C_{i, t}^{1-\sigma}+\beta_{i, t}\left[E_{t} U_{i, t+1}^{1-\gamma_{i, t}}\right]^{(1-\sigma) /\left(1-\gamma_{i, t}\right)}\right\}^{1 /(1-\sigma)},
$$

where $U_{i, t}$ is life-time utility at date t. $0<\beta_{i, t}<1$ is the country's subjective discount factor between periods $t$ and $t+1,1 / \sigma$ is the intertemporal elasticity of substitution (IES). $\gamma_{i, t}$ indexes the country's aversion at date $t$ against uncertainty in future life-time utility. Note that time-separable utility obtains when $\gamma_{i, t}=\sigma$. Epstein, Zin and Weil assume a 
version of (4) in which $\beta_{i, t}$ and $\gamma_{i, t}$ are constant parameters. Much of the analysis below likewise assumes constant risk aversion $\gamma_{i, t}=\gamma$. In order to ensure that the model has a unique deterministic steady state and an equilibrium in which the consumption/output and net foreign assets/output ratios are stationary (which allows to solve the model numerically using standard techniques, see below), I assume that the subjective discount factor of household $i$ is a decreasing function of its consumption/output ratio: $\beta_{i, t}=\beta\left(C_{i, t} / Y_{i, t}\right)$, with $\beta^{\prime}<0 .{ }^{5}$ In the numerical simulations, $\beta^{\prime}$ is set at a very small (absolute) value. For simplicity, I assume that the dependence of the discount factor on consumption is not internalized by households, i.e. that the country $i$ representative households treats $\beta_{i, t}$ as exogenous. ${ }^{6}$

Country $i$ 's intertemporal marginal rate of substitution (IMRS) between aggregate consumption at dates $t$ and $t+1$ is:

$$
\rho_{i, t+1} \equiv \beta_{i, t} \frac{1-\beta_{i, t+1}}{1-\beta_{i, t}}\left(\frac{C_{i, t+1}}{C_{i, t}}\right)^{-\sigma}\left(\frac{U_{i, t+1}}{\left(E_{t} U_{i, t+1}^{1-\gamma_{i, t}}\right)^{1 /\left(1-\gamma_{i, t}\right)}}\right)^{\sigma-\gamma_{i, t}} .
$$

The baseline model assumes complete international financial markets. In equilibrium, the ratio of the two household's IMRSs is thus equated to the growth factor of the real exchange rate (Kollmann (1991, 1995), Backus and Smith (1993)):

$$
R E R_{t+1} / R E R_{t}=\rho_{H, t+1} / \rho_{F, t+1} .
$$

Let $N F A_{i, t+1}$ denote country i's net foreign assets at the end of period t. $N F A_{i, t+1}$ equals the present discounted value of $i$ 's future net imports. In recursive form: $N F A_{i, t+1} \equiv E_{t} \rho_{i, t+1}\left(P_{i, t} / P_{i, t+1}\right)\left(N F A_{i, t+2}-N X_{i, t+1}\right)$, where $N X_{i, t+1} \equiv p_{i, t+1} Y_{i, t+1}-P_{i, t+1} C_{i, t+1}$ are net

\footnotetext{
${ }^{5}$ When $\gamma \neq \sigma$ the linearized model has a unit root if the subjective discount factor is constant. This is due to the fact that the intertemporal marginal rate of substitution depends on innovations to future life-time utility when $\gamma \neq \sigma$ (see (5) and (6) below). When $\beta$ is constant, those innovations drive a permanent wedge between Home and Foreign consumption. (This is the case even when output is stationary.) Setting $\beta^{\prime}<0$ ensures stationarity of the consumption/output ratio, as a country that receives a positive international wealth transfer will gradually decrease her consumption/output ratio in subsequent periods (due to greater impatience), until that ratio has converged back to its steady state value. The open economy literature has widely assumed endogenous subject discount factors to induce stationarity; e.g., Obstfeld (1981a,b), Lucas and Stokey (1984), Kollmann (1991), Schmitt-Grohé and Uribe (2003).

${ }^{6}$ To justify this, assume that country $i$ has a continuum of identical households, and that $\beta_{i, t}$ depends on aggregate consumption/output. Then an individual household has no influence on $\beta_{i, t}$. This resembles the assumption in 'external' habit formation models that households take the habit stock as exogenous.
} 
exports at $t+1$. Empirically, $N F A_{i, t+1}$ corresponds to the market value of net foreign assets at the end of period $t$.

Empirical fluctuations of output and of relative output are highly persistent. I assume that output has a unit root, while relative output is stationary but highly serially correlated. Specifically, Home and Foreign output are assumed to follow an errorcorrection mechanism with heteroskedastic disturbances:

$$
\Delta \ln \left(Y_{i, t+1}\right)=-\kappa \cdot\left[\ln \left(Y_{i, t}\right)-\ln \left(Y_{j, t}\right)\right]+e^{s_{i, t}} \lambda_{i} \varepsilon_{i, t+1}^{Y}, \quad s_{i, t}=\rho_{i} s_{i, t}+\phi_{i} \varepsilon_{i, t}^{s} \quad \text { for } i=H, F \text { and } j \neq i,
$$

with $\kappa, \lambda_{i}, \phi_{i}>0$ and $0<\rho_{i}<1 . \quad \varepsilon_{i, t+1}^{Y}$ and $\varepsilon_{i, t}^{s}$ are exogenous $\mathrm{N}(0,1)$ white noises. $\varepsilon_{H, t+1}^{Y}$ and $\varepsilon_{F, t+1}^{Y}$ are correlated, but $\varepsilon_{i, t+1}^{Y}$ is independent of $\varepsilon_{i, t+1}^{s}$ for $i, j=$ H,F. $s_{i, t}$ is time-varying output volatility. The unconditional standard deviation of the date $\mathrm{t}+1$ output innovation is $\lambda_{i} e^{2 V_{s, i}}$, where $V_{s, i} \equiv\left(\phi_{i}\right)^{2} /\left(1-\rho_{i}^{2}\right)$ is the variance of $s_{i, t}$. The parameter $\lambda_{i}$ indexes thus the standard deviation of output innovations; $\rho_{i}$ determines the persistence of output volatility, while $\phi_{i}$ is the standard deviation of innovations to output volatility.

\subsection{Numerical solution method}

As output is assumed non-stationary, but cointegrated across countries, I reformulate the model by normalizing country $i$ consumption, net exports, net foreign assets and utility by i's output. The reformulated model is solved using a third-order approximation around the symmetric deterministic steady state. The Dynare toolbox is used for that purpose (Adjemian et al. (2014)). I simulate the model and compute moments of endogenous variables using the pruned state-space representation of the third-order accurate model solution (Kollmann (2005, 2015a), Andreasen et al. (2013)).

\subsection{Calibration}

\subsubsection{Preference and technology parameters}

One period represents one quarter. The steady state subjective discount factor is set at $\beta=0.99$. I assume that, in the neighborhood of the deterministic steady state, the subjective discount factor is linear in the log consumption/output ratio: 
$\beta_{i, t}=0.99-b \cdot \ln \left(C_{i, t} / Y_{i, t}\right)$, with $b=0.001 .^{7}$ The intertemporal substitution elasticity $1 / \sigma$ is set at 1.5 in line with standard values of that parameter used in the DSGE literature (results are robust to assuming other values of $1 / \sigma$ in the same range). Following the macro-finance literature that assumes recursive preferences (e.g., Dew-Becker (2014), Swanson (2014)), I consider high risk aversion coefficients: $\gamma=10,30,60$.

As discussed below, I calibrate the endowment process to quarterly 1973-2014 data for the US and for an aggregate of 23 other OECD economies (henceforth referred to as 'rest of the world', ROW) for which quarterly national accounts data for that period are available in the OECD national accounts database. ${ }^{8}$ In 1973-2014, the mean US trade share $(0.5 *$ (exports+imports)/GDP) was $10 \%$. Hence, I set the home bias parameter at $\alpha=0.9$. The substitution elasticity between domestic and imported goods is set at $\phi=1$, as empirical estimate of the price elasticity of aggregate imports and exports are generally in the range of unity (e.g., Kollmann (2001)).

\subsubsection{Endowment process}

The model abstracts from physical investment and government purchases. Like other papers that use models of endowment economies without government to study the dynamics of the external balance (e.g., Engle and Rogers (2006)), I consider an empirical real output measure that equals GDP minus investment minus government purchases ('net GDP'), or equivalently, private consumption plus net exports: $G D P_{i, t}^{n e t}=\left(C_{i, t}^{n o m}+X_{i, t}^{n o m}-M_{i, t}^{\text {nom }}\right) / P_{i, t}^{G D P}$, where $C_{i, t}^{\text {nom }}, X_{i, t}^{\text {nom }}$ and $M_{i, t}^{\text {nom }}$ are nominal consumption, exports and imports (in domestic currency) respectively, while $P_{i, t}^{G D P}$ is the GDP deflator. ${ }^{9}$ ROW net GDP is computed as a geometric weighted average of real net GDP indices for the 23 countries included in the ROW aggregate. ${ }^{10}$

\footnotetext{
${ }^{7}$ That small value of the slope parameter $b$ implies that the short term dynamics of the model are similar to those generated by a (non-stationary) model variant with a constant subjective discount factor $(b=0)$.

${ }^{8}$ The 23 ROW countries are: Australia, Austria, Belgium, Canada, Denmark, Finland, France, Germany, Greece, Ireland, Italy, Japan, Korea, Mexico, Netherlands, New Zealand, Norway, Portugal, Spain, Sweden, Switzerland, Turkey and the United Kingdom.

${ }^{9}$ I do not construct the empirical net output series as GDP-investment-government purchases, because of gaps in the OECD investment data.

${ }^{10}$ I use time-varying real GDP weights (based on countries' real GDP at fixed PPPs, in USD of base year 2010) to compute the ROW aggregates. Constant weights give very similar results.
} 
The parameters $\lambda_{i}, \rho_{i}, \phi_{i}$ of the endowment process (7) are estimated with quarterly US and ROW net GDP data (1973-2014), using the quasi-maximum likelihood method of Harvey et al. (1994). The estimates are as follows (standard deviations are shown in parentheses):

\begin{tabular}{|l|l|l|l|l|l|}
\hline$\lambda_{\text {US }}$ & $\rho_{U S}$ & $\phi_{U S}$ & $\lambda_{\text {ROW }}$ & $\rho_{\text {ROW }}$ & $\phi_{\text {ROW }}$ \\
\hline $0.56 \%$ & 0.99 & $5.81 \%$ & 0.62 & 0.91 & $8.98 \%$ \\
$(0.14 \%)$ & $(0.02)$ & $(3.76 \%)$ & $(0.07)$ & $(0.10)$ & $(8.43 \%)$ \\
\hline
\end{tabular}

Hence, US and ROW net output innovations have similar standard deviations of about $0.6 \%\left(\lambda_{U S}, \lambda_{R O W}\right)$. Innovations to the output volatility process have smaller standard deviations in the US than in the ROW $\left(\phi_{U S}<\phi_{R O W}\right)$, but US volatility is more persistent $\left(\rho_{U S}>\rho_{R O W}\right)$. Note that the volatility parameters $\phi_{i}$ and $\rho_{i}$ are estimated more precisely for the US than for the ROW. Therefore, and for the sake of symmetry, I set the parameters of both countries' output processes at US estimates: $\lambda_{i}=0.56 \%, \rho_{i}=0.99$, $\phi_{i}=5.81 \%$ for $i=H, F^{11}$

An Augmented Dickey-Fuller test fails to reject the hypothesis that relative US/ROW net GDP has a unit root. To ensure stationarity of the normalized model, I set the output error correction parameter (see (7)) at a very small positive value, $\kappa=0.001$. The empirical correlation between US and ROW net output growth is 0.19. I set the correlation of $\varepsilon_{H, t}^{Y}$ and $\varepsilon_{F, t}^{Y}$ at 0.22 , as this reproduces the empirical cross-country correlation of net output (given the calibrated values of $\lambda_{i}, \rho_{i}, \phi_{i}$ and $\kappa$ ).

\subsubsection{Exogenous fluctuations in risk appetite}

Some of the simulations below postulate exogenous fluctuations in risk appetite; there, the aversion parameter $\gamma_{i, t}$ is assumed to follows an AR(1) process:

$$
\ln \left(\gamma_{i, t} \overline{l \gamma}\right)=\rho_{\gamma} \ln \left(\gamma_{i, t} \bar{l}\right)+\psi \varepsilon_{i, t}^{\gamma} \text { for } i=\mathrm{H}, \mathrm{F}
$$

\footnotetext{
${ }^{11}$ An asymmetric calibration that uses the US [ROW] parameter estimates reported in the above Table for the country $\mathrm{H}[\mathrm{F}]$ output process gives predictions that are close to those obtained for the symmetric calibration (contributions of volatility shocks to fluctuations in consumption, net exports, the real exchange rate are similar etc.).
} 
where $\varepsilon_{i, t}^{\gamma}$ is an exogenous $\mathrm{N}(0,1)$ white noise that is independent of all other exogenous variables. Dew-Becker (2014) estimates a quarterly closed economy New Keynesian DSGE model with recursive preferences and time-varying risk aversion that follows an AR(1) process. His estimates (based on US data) of the autocorrelation of risk aversion and of the innovation of risk aversion are 0.90 and 0.34 , respectively. For illustrative purposes, I thus set $\rho_{\gamma}=0.90, \psi=0.34$, in the variants of my model with exogenous risk appetite shocks. $^{12}$

\section{Empirical regularities}

Table 1 reports historical business cycle statistics (1973q1-2014q4) for US and ROW net GDP, consumption, net exports and net foreign assets (normalized by domestic net GDP), and the effective real exchange rate. The statistics pertain to quarterly first differenced data, with the exception of (normalized) net foreign assets for which first differences of annual data are used. Net GDP, consumption and the real exchange rate are logged before first differencing. The standard deviation of net GDP growth (about $0.7 \%$ ) is very similar across the US and the ROW. Consumption and net exports are less volatile than net GDP. Net foreign assets and the real exchange rate are markedly more volatile than net GDP. Consumption and net exports are positively correlated with domestic net GDP. Net foreign assets and the real exchange rate are only weakly correlated with net GDP. The cross-country correlation of consumption growth (0.30) is higher than that of output growth (0.19). The correlation between relative US/ROW consumption growth and the rate of appreciation of the US real exchange rate is 0.15 (not reported in Table), i.e. relative consumption is weakly positively correlated with the real exchange rate.

\section{Model predictions}

Tables 2-4 report predicted standard deviations and cross-correlations of key variables generated by different model variants. Predicted moments of output, consumption and the real exchange rate pertain to log first differenced variables, while moments for net

\footnotetext{
${ }^{12}$ Dew-Becker (2014) reports an estimate of the steady state risk aversion coefficient $\bar{\gamma}=23.4$. Below, I consider a range of values for $\bar{\gamma}$.
} 
exports pertain to first differenced net exports normalized by domestic GDP; moments for NFA pertain to annual differences of net foreign assets normalized by annual GDP. ${ }^{13}$ The Tables also reports the Hansen-Jagannathan (1991) bound ['HJ bound'] generated by the model, i.e. the ratio of the standard deviation of the intertemporal marginal rate of substitution (IMRS) divided by the mean IMRS. That statistic allows to evaluate whether the model has the potential to generate realistic risk premia on financial assets. In equilibrium, the Sharpe ratio of any traded risky asset is bounded above by the HJ bound. The historical quarterly Sharpe ratio of US equity returns was 0.22 in 1973-2014. ${ }^{14}$ Thus, a model-generated $\mathrm{HJ}$ bound below 0.22 indicates that the model cannot generate a realistic equity premium.

Table 2 shows predicted moments for the baseline complete markets model with output level and volatility shocks. In Cols. (1)-(3), the risk aversion coefficient is set at the inverse of the intertemporal elasticity of substitution (IES): $\gamma=1 / \mathrm{IES}=0.66$; this specification corresponds to standard time-separable utility (recall that IES=1.5).

Columns labelled ' $Y$,s' show predicted model moments under simultaneous output level and volatility shocks. To disentangle the effect of level and volatility shocks, I also show predicted moments that are generated when just output level shocks are fed into the equilibrium decision rules (holding the volatility shocks constant at $s_{i, t}=0$ ), as well as predicted moments that obtain when just volatility shocks are fed into the decision rules (see Cols. labeled ' $Y$ ' and 's', respectively). ${ }^{15}$

Cols. (1)-(3) of Table 2 show that the model variant with time-separable utility $(\gamma=1 /$ IES) exhibits well-known shortcomings of standard International Real Business Cycle models (e.g., Backus et al. (1994)): the predicted volatility of the real exchange rate, net exports and net foreign assets is much smaller than empirical volatility. The variant also predicts that relative consumption growth is perfectly negatively correlated

\footnotetext{
${ }^{13} \mathrm{Net}$ exports and net foreign assets are normalized by output (e.g., $\left.N X_{i, t} /\left(p_{i, t} Y_{i, t}\right)\right)$ before quarterly/annual differences are computed.

${ }^{14}$ The Sharpe ratio is defined as the ratio of an asset's average excess return (relative to a risk-free return), divided by the standard deviation of the excess return. The historical Sharpe ratio reported in the text was constructed using returns data from Kenneth French's web page. The historical quarterly equity Sharpe ratio was 0.19 in 1926-2014.

${ }^{15}$ A simulated path with just volatility shocks represent a path in which realized output innovations equal zero $\left(\varepsilon_{i, t}^{Y}=0\right)$ for all periods, but in which volatility $S_{i, t}$ fluctuates randomly.
} 
with the rate of real exchange rate appreciation, which likewise is inconsistent with the data. Also, the HJ bound generated by the model variant with $\gamma=1 /$ IES is close to zero, i.e. that variant cannot generate a realistic equity premium. In this model variant, volatility shocks have no effect on consumption, the real exchange rate, net exports and net foreign assets (see Col. (3)).

Cols. (4)-(12) of Table 2 consider 3 values of the risk aversion coefficient $\gamma$ that exceed 1/IES: $\gamma=10,30,60$. These recursive-preferences model variants generate sizable IMRS fluctuations, as the IMRS is affected by shocks to expected life-time utility when $\gamma>1 /$ IES (see (5)). The model variants with $\gamma=10, \gamma=30$ and $\gamma=60$ generate HJ bounds of $0.05,0.15$ and 0.34 , respectively. Substantial risk aversion is thus needed to generate a realistic HJ bound. Due to the greater volatility of the IMRS, the model variants with $\gamma=10,30$ and 60 generate markedly more volatile real exchange rates, net exports and net foreign assets than the model variant with time-separable utility. Predicted volatility is greater, the higher the risk aversion coefficient. Importantly, the model variants with $\gamma>1 /$ IES predict that volatility shocks have a noticeable effect on consumption, the real exchange rate, net exports and net foreign assets. For example, when $\gamma=30$, the predicted standard deviations of these four variables are $0.13 \%, 0.49 \%, 0.08 \%$ and $3.19 \%$, respectively, when just volatility shocks are fed into the equilibrium decision rules (see Col. (9)). The corresponding predicted standard deviations are $0.53 \%, 1.68 \%, 0.17 \%$ and 8.11\%, respectively, with simultaneous level and volatility shocks. Thus, the predicted volatility of the real exchange rate and of net foreign assets (with both shock types) is roughly in the range of empirical volatility (see Col. (13)); however, net exports remain insufficiently volatile.

With just output level shocks (and a constant volatility), consumption is almost perfectly correlated across countries in the model variants with $\gamma>1 /$ IES, and furthermore relative consumption and the real exchange rate are (almost) perfectly negatively correlated (see Cols, (5), (8) and (11)). These predictions are counterfactual. By contrast, volatility shocks induce consumption fluctuations that are perfectly negatively correlated across countries, and fluctuations in relative consumption that are perfectly positively correlated with the real exchange rate (Cols. (6), (9) and (12)). However, with 
simultaneous output level and volatility shocks, the predicted correlation between relative consumption and the real exchange rate is much closer to the empirical correlation, for $\gamma=30$ and when $\gamma=60$ (predicted correlations: -0.14 and 0.39 , respectively). For $\gamma=30$, the predicted cross-country consumption correlation (0.83) remains much too high, when compared to the data. Higher risk aversion $(\gamma=60)$ is required to generate a more realistic predicted cross-country consumption correlation (0.49).

Panel (a) of Table 5 shows dynamic effects of a one-standard deviation Home output level shock in the model variant with time separable utility $(\gamma=1 / \mathrm{IES})$. The shock triggers a persistent rise in Home output, and it leads to a very gradual rise in Foreign output. International risk sharing implies that Home sends part of its higher output to Foreign. However, due to the strong Home bias in consumption, Foreign consumption rises much less than Home consumption. There is a modest Home real exchange rate depreciation.

Panel (b) of Table 5 shows dynamic responses to Home output level and volatility shocks, for risk aversion $\gamma=30$. A positive level innovation to Home output raises Home life-time utility which reduces the Home IMRS between the period preceding the shock and the period of the shock (see equation (5)). This implies that a rise in Home output triggers a much more muted rise in Home consumption than in the model variant with $\gamma=1 /$ IES, while Foreign consumption rises much more. The more muted rise in Home consumption when $\gamma>1 /$ IES implies that the Home real exchange rate depreciates strongly. On impact, a $0.56 \%$ Home output innovation depreciates the Home real exchange rate by $1.1 \%$. Home net exports rise noticeably (by $10 \%$ of output) and persistently, and thus Home net foreign assets (the present value of Home net imports) fall sharply (by $-9.9 \%$ of quarterly output). The strong rise in Foreign consumption explains why the cross-country consumption correlation is so high, when $\gamma=30$ (as discussed above). Note that the effects of the output level shock on net exports and the real exchange rate are highly persistent.

Panel (b) of Table 5 also shows dynamic responses to a positive one standard deviation innovation to Home output volatility. An unexpected rise in volatility $S_{H, t}$ lowers Home life-time utility. When $\gamma>1 /$ IES, this raises the Home IMRS between the 
period preceding the volatility shock and the date of the shock, and thus the shock leads to a surprise appreciation of the Home real exchange rate (see (6)), and to an improvement of the Home terms of trade (due to consumption home bias). Goods market clearing requires, hence, that Home relative consumption rises. ${ }^{16}$ At unchanged output levels, this implies that Home consumption increases, while Foreign consumption falls, so that Home net exports drop. The responses of consumption, the real exchange rate and net exports to a volatility shock are highly persistent. This explains why Home net foreign assets rise strongly (and persistently), i.e. Home receives a sizable wealth transfer from Foreign. These dynamic responses also help to understand why, under recursive preferences, volatility shocks induce consumption fluctuations that are negatively correlated across countries, and fluctuations in relative consumption growth that are positively correlated with the real exchange rate appreciation (see above).

Overall, the simulations suggest that the recursive preferences-complete markets model with output level and volatility shocks can capture key empirical regularities better than a structure with constant output volatility. In that model, volatility shocks have a noticeable effect on net exports, the real exchange rate and net foreign assets.

\section{Shocks to risk aversion}

It is often argued informally that, like volatility shocks, changes in investors' risk appetite can be important drivers of gross and net international capital flows, and of the real exchange rate (e.g., IMF (2011)). However, this notion has not yet been explored using quantitative dynamic general equilibrium models. I thus use the model here to assess the effect of exogenous shifts in agents' risk aversion.

Table 3 reports predicted moments generates by a model variant that assumes risk aversion shocks (as well as output level and volatility shocks). Three values of the steady state risk aversion coefficient are considered: $\bar{\gamma}=10,30,60$ (see equation (8)). Table 5 (Panel (b)) shows dynamic responses to a risk aversion shock (for $\bar{\gamma}=30$ ). The

\footnotetext{
${ }^{16}$ The goods demand functions (3) imply that relative world demand for good $\mathrm{H}$ (divided by world demand for good F) is a decreasing function of the Home terms of trade $q$, and an increasing function of Home relative consumption $C_{H} / C_{F}$. Thus, holding output constant, any shock that improves the Home terms of trade has to be accompanied by a rise in Home relative consumption.
} 
simulations show that risk aversion shocks have a noticeable effect on consumption, the real exchange rate, net exports and net foreign assets.

Like volatility shocks, the risk aversion shocks induce consumption fluctuations that are perfectly negatively correlated across countries, and perfectly positively correlated with the real exchange rate. Qualitatively, the dynamic effects of a positive shock to risk aversion are similar to those of a positive volatility shock. A rise in a country's risk aversion lowers its life-time utility; under recursive preferences and complete markets, this implies that, on impact, the country receives a wealth transfer from the rest of the world, and thus the country's consumption and her NFA rise, and her real exchange rate appreciates. However, these responses are more transitory than the effects of volatility shocks.

Table 3 suggests that a model variant with all three types of shocks (output level and volatility shocks, and risk aversion shocks) is best suited for explaining the volatility of the real exchange rate, net exports and net foreign assets seen in the data; such a model variant can also match much better the low empirical cross-country correlation of consumption.

\section{Incomplete financial markets}

The transmission of volatility and risk aversion shocks is sensitive to the structure of international asset markets. To illustrate this, I consider a model variant in which just an unconditional bond can be traded internationally, i.e. in which the global financial market is incomplete. ${ }^{17}$ To keep symmetry between the two countries, I assume that the bond is denominated in a basket consisting of half a unit of the Home output good, and half a unit of the Foreign good (as in Kollmann (2015b)). Country $i$ thus faces the budget constraint:

$$
\frac{1}{2}\left(p_{1, t}+p_{2, t}\right) N F A_{i, t+1}+P_{i, t} C_{i, t}=p_{i, t} Y_{i, t}+\frac{1}{2}\left(p_{1, t}+p_{2, t}\right) N F A_{i, t}\left(1+r_{t}^{A}\right),
$$

where $N F A_{i, t+1}$ represents bond holdings at the end of period $t$, while $r_{t}^{A}$ is the bond rate between periods $t-1$ and $t$. The households' Euler equation with respect to the bond are:

$$
\left(1+r_{t+1}^{A}\right) E_{t}\left(P_{i, t} / P_{i, t+1}\right)\left(\left(p_{H, t+1}+p_{F, t+1}\right) /\left(p_{H, t}+p_{F, t}\right)\right) \rho_{i, t+1}=1 \text { for } i=H, F \text {. }
$$

\footnotetext{
17 'Bonds-only' asset structures have widely been assumed in open economy macro models; e.g., Baxter and Crucini (1995), Kollmann (1991, 1996), Obstfeld and Rogoff (1996), Benigno and Thoenissen (2008).
} 
In the bonds-only structure, the risk aversion coefficient $\gamma$ does not affect equilibrium quantities and prices, up to a linear model approximation-for given intertemporal elasticity of substitution (IES), a recursive preferences set-up with $\gamma \neq 1 /$ IES is thus observationally equivalent to a set-up with time-separable utility ( $\gamma=1 /$ IES), up to first order. ${ }^{18}$ When a third-order model approximation is used, a bonds-only structure with $\gamma \neq 1 /$ IES remains quantitatively very similar to a set-up with $\gamma=1 /$ IES, and the effects of volatility and risk aversion shocks are markedly more muted than under complete markets. Intuitively, market incompleteness hinders the cross-country wealth transfers that occur under efficient risk sharing, in response to shocks to future life-time utility. ${ }^{19}$

Table 4 reports predicted moments for a bonds-only model variant with output level, volatility and risk aversion shocks. The steady state risk aversion coefficient is set at $\bar{\gamma}=30$. The bonds-only variant generates standard deviations of the real exchange rate, net exports and net foreign assets that are much too small when compared to the data. Also, that model variant predicts that the growth rate of relative consumption is highly negatively correlated with the real exchange rate appreciation rate. Impulse responses reported in Panel (c) of Table 5 show that, in the bonds-only variant, increases in Home output volatility and in Home risk aversion trigger a slight fall in Home consumption, due to a rise in Home precautionary saving. This depreciates the Home real exchange rate, raises Home net exports, and leads to a gradual rise in Home net foreign assets.

Fogli and Perri (2014) and Hoffmann et al. (2014) document a positive empirical correlation between a country's (relative) output volatility and its net foreign assets. A bonds-only model reproduces that stylized fact via a precautionary saving channel. As mentioned above, the recursive preferences-complete markets model studied in the present paper predicts likewise that a rise in volatility leads to higher net foreign assets,

\footnotetext{
${ }^{18}$ (9) implies that, up to first order $E_{t} \rho_{i, t+1}=-E_{t} R_{i, t+1}$ holds where $R_{i, t+1} \equiv\left(1+r_{t+1}^{A}\right)\left(P_{i, t} / P_{i, t+1}\right)\left(p_{H, t+1}+p_{F, t+1}\right) /\left(p_{H, t}+p_{F, t}\right)$ and hatted variables $(\wedge)$ represent relative deviations from steady state. Note that $E_{t} \rho_{i, t+1} \approx-\sigma C_{H, t+1} / C_{H, t}$, i.e. the expected IMRS does not depend on risk aversion or on innovations to future life-time utility (to firstorder). Thus, risk aversion does not affect the equilibrium in a bonds-only economy (to first order).

${ }^{19}$ In the bonds-only model variant, the risk sharing condition (6) fails to hold. Up to a first order approximation, (9) implies merely that expected real exchange rate appreciation equals the expected ratio of the two countries' intertemporal marginal rates of substitution: $E_{t} \Delta R E R_{t+1}=E_{t}\left(\rho_{H, t+1}-\rho_{F, t+1}\right)$.
} 
but the mechanism here is different: it reflects a wealth transfer received by a country that experiences a positive volatility shock.

\section{Conclusion}

This paper has analyzed the effects of uncertainty shocks and of risk appetite shocks on the dynamics of consumption, trade flows and the real exchange rate, in a two-country world with recursive preferences and complete financial markets. When the risk aversion coefficient exceeds the inverse of the intertemporal substitution elasticity, then an exogenous rise in a country's output volatility triggers a wealth transfer to that country, in equilibrium; this raises its consumption, lowers its trade balance and appreciates its real exchange rate. The effects of shocks to risk appetite resemble those of volatility shocks. In a recursive preferences-complete markets framework, volatility and risk appetite shocks account for a noticeable share of the fluctuations of net exports, net foreign assets and the real exchange rate. These shocks help to explain the high empirical volatility of the real exchange rate and they provide a possible solution for the consumption-real exchange rate puzzle. 


\section{References}

Adjemian, Stéphane, Houtan Bastani, Frédéric Karamé, Michel Juillard, Junior Maih, Ferhat Mihoubi, George Perendia, Johannes Pfeifer, Marco Ratto and Sébastien Villemot, 2014. Dynare: Reference Manual, Version 4.4.3, CEPREMAP, Paris.

Andreasen, Martin, Jesus Fernández-Villaverde and Juan Rubio-Ramírez, 2013. The Pruned State-Space System for Non-Linear DSGE Models: Theory and Empirical Applications. NBER Working Paper 18983.

Backus, David, and Gregor Smith, 1993. Consumption and Real Exchange Rates in Dynamic Economies with Non-traded Goods. Journal of International Economics 35, 297-316.

Backus, David, Patrick Kehoe, and Finn Kydland, 1992. International Real Business Cycles. Journal of Political Economy, 100, 745-775.

Backus, David, Chase Coleman, Axelle Ferriere and Spencer Lyon, 2015. Risk and Risksharing in Two-Country Models. Mimeo, NYU.

Baxter, Marianne and Mario Crucini, 1995. Business Cycles and the Asset Structure of Foreign Trade. International Economic Review 36, 821-54.

Benigno, Gianluca and Christoph Thoenissen, 2008. Consumption and Real Exchange Rates with Incomplete Markets. Journal of International Money and Finance 27, 926-48.

Bloom, Nicolas, 2014. Fluctuations for Uncertainty. Journal of Economic Perspectives 28, 153-176.

Born, Benjamin and Johannes Pfeifer, 2014. Risk Matters: The Real Effects of Volatility Shocks: Comment. American Economic Review 104, 4231-4239.

Colacito, Riccardo and Mariano Croce, 2011. Risks for the Long Run and the Real Exchange Rate. Journal of Political Economy 119, 153-182.

Colacito, Riccardo and Mariano Croce, 2013. International Asset Pricing with Recursive Preferences. Journal of Finance 68, 2651-2686.

Caporale, Guglielmo Maria, Michael Donadelli and Alessia Varani, 2014. International Capital Markets Structure, Preferences and Puzzles: The US-China Case. CESifo Working Paper 4669.

Devereux, Michael B. and Robert Kollmann, 2012. Symposium on International Risk Sharing: Introduction. Canadian Journal of Economics 45, 373-375.

Dew-Becker, Ian, 2015. Bond Pricing with a Time-Varying Price of Risk in an Estimated Medium-Scale Bayesian DSGE Model. Journal of Money, Credit and Banking 46, 837888.

Engel, Charles and John Rogers, 2006. The U.S. Current Account Deficit and the Expected Share of World Output. Journal of Monetary Economics 53, 1063-1093.

Epstein, Larry and Stanley Zin, 1989. Substitution, Risk Aversion, and the Temporal Behavior of Consumption and Asset Returns: A Theoretical Framework. Econometrica 57, 937-969.

Fernandez-Villaverde, Jesus, Pablo Guerron-Quintana, Juan Rubio-Ramirez and Martin Uribe, 2011. Risk Matters: The Real Effects of Volatility Shocks. American Economic Review 101, 2530-2561.

Fogli, Alessandra and Fabrizio Perri, 2014. Macroeconomic Volatility and External Imbalances. Journal of Monetary Economics 69, 1-15.

Gourio, François, Michael Siemer and Adrien Verdelhan, 2013. International Risk Cycles. Journal of International Economics 89, 471-484.

Hansen, Lars Peter and Ravi Jagannathan, 1991. Implications of Security Market Data for Models of Dynamic Economies. Journal of Political Economy 99, 225-262. 
Harvey, Andrew, Esther Ruiz and Neil Shephard, 1994. Multivariate Stochastic Variance Models. Review of Economic Studies 61, 247-264.

Hoffmann, Mathias, Michael Krause and Peter Tillmann, 2014. International Capital Flows, External Assets and Output Volatility. Working Paper, Deutsche Bundesbank.

International Monetary Fund, 2013. The External Balance Assessment (EBA) Methodology. IMF/13/272.

Kollmann, Robert, 1991. Essays on International Business Cycles. PhD Dissertation, Economics Department, University of Chicago.

Kollmann, Robert, 1995. Consumption, Real Exchange Rates and the Structure of International Asset Markets. Journal of International Money and Finance 14, 191-211.

Kollmann, Robert, 1996. Incomplete Asset Markets and the Cross-Country Consumption Correlation Puzzle. Journal of Economic Dynamics and Control 20, 945-962.

Kollmann, Robert, 2001. The Exchange Rate in a Dynamic-Optimizing Business Cycle Model with Nominal Rigidities: A Quantitative Investigation. Journal of International Economics 55, 243-262.

Kollmann, Robert, 2005. Solving Non-Linear Rational Expectations Models: Approximations based on Taylor Expansions. Working Paper, University Paris XII.

Kollmann, Robert, 2009. EZW in a World Economy. Working Paper, ECARES, Université Libre de Bruxelles.

Kollmann, Robert, Zeno Enders, and Gernot Müller, 2011. Global Banking and International Business Cycles. European Economic Review 55, 407-426.

Kollmann, Robert, 2012. Limited Asset Market Participation and the Consumption-Real Exchange Rate Anomaly. Canadian Journal of Economics 45, 566-584.

Kollmann, Robert, 2015a. Tractable Latent State Filtering for Non-Linear DSGE Models Using a Second-Order Approximation and Pruning. Computational Economics 45, 239260.

Kollmann, Robert, 2015b. Exchange Rate Dynamics with Long-Run Risk and Recursive Preferences. Open Economies Review 26, 175-196.

Lewis, Karen and Edith Liu, 2014. Evaluating International Consumption Risk Sharing Gains: An Asset Return View. Forthcoming, Journal of Monetary Economics.

Lucas, Robert and Nancy Stokey, 1984. Optimal Growth With Many Consumers. Journal of Economic Theory 32, 139-171.

Mumtaz, Haroon and Konstantinos Theodoridis, 2015. Common and Country Specific Economic Uncertainty. Working Paper 752, Queen Mary College, London.

Obstfeld, Maurice, 1981a. Capital Mobility and Devaluation in an Optimizing Model With Rational Expectations. American Economic Review 71, 217-221.

Obstfeld, Maurice, 1981b. Macroeconomic Policy, Exchange Rate Dynamics, and Optimal Asset Accumulation. Journal of Political Economy 89, 1142-1161.

Obstfeld, Maurice and Kenneth Rogoff, 1996. Foundations of International Macroeconomics (Cambridge, MA: MIT Press)

Obstfeld, Maurice and Kenneth Rogoff, 2000. The Six Major Puzzles in International Macroeconomics: Is There a Common Cause? NBER Macro Annual 15, 339-390.

Sauzet, Maxime, 2014. Great Retrenchment, Financial Contagion and International RiskSharing. Working Paper, Sciences Po, Paris.

Schmitt-Grohé, Stephanie and Martin Uribe, 2003. Closing Small Open Economy Models Journal of International Economics 61, 163-85

Swanson, Eric, 2014. A Macroeconomic Model of Equities and Real, Nominal, and Defaultable Debt. Working Paper, UC Irvine. 
Tretvoll, Hakan, 2013. Real Exchange Rate Variability in a Two-Country Business Cycle Model. Working Paper, Bergen University.

Weil, Philippe, 1989. The Equity Premium Puzzle and the Risk-Free Rate Puzzle. Journal of Monetary Economics 24, 401-421.

Weil, Philippe, 1990. Nonexpected Utility in Macroeconomics, Quarterly Journal of Economics 105, 29-42. 
Table 1. Historical statistics (1973q1-2014q4)

US

0.69

0.70

Net GDP

Consumption

Real exchange rate

Net exports/(net GDP)

Net foreign assets/(net GDP)
0.64

2.42

0.52

7.44

0.73

0.73

$-0.12$

n.a.

0.36

0.58

0.16

n.a.

\section{Cross-country correlations}

Net GDP

Consumption

Notes: Empirical statistics are shown for macroeconomic variables in the US and in an aggregate of 23 other OECD economies ('ROW'). The statistics pertain to first differenced quarterly data, with the exception of net foreign assets (normalized by annual net GDP) for which first differences of annual data are used. Net GDP (GDP minus investment and government purchases), consumption and the real exchange rate are logged before first differencing. ROW aggregate consumption is a weighted geometric average of real consumption in the 23 ROW countries. ROW net exports/(net GDP) is constructed as the sum of nominal next exports in the 23 ROW countries (in current dollars), divided by the sum of nominal net GDP in the 23 countries (in current dollars, based on the current nominal exchange rate). Due to limited data availability, statistics for the effective real exchange rate and net foreign assets are only shown for the US. The real exchange rate is an effective rate (CPI based), from OECD MEI. US Net foreign assets data are from the Bureau of Economic Analysis. Other series are from OECD quarterly national accounts. 
Table 2. Predicted moments: complete markets model with shocks to output level \& volatility

\begin{tabular}{|c|c|c|c|c|c|c|c|c|c|c|c|c|c|}
\hline \multirow{2}{*}{\multicolumn{4}{|c|}{$\begin{array}{c}\frac{\text { Risk aversion } \gamma=1 / \text { IES }}{\text { Shocks to: }} \\
Y, S \quad Y\end{array}$}} & \multicolumn{3}{|c|}{$\frac{\text { Risk aversion } \gamma=10}{\text { Shocks to: }}$} & \multicolumn{3}{|c|}{$\frac{\text { Risk aversion } \gamma=30}{\text { Shocks to: }}$} & \multicolumn{3}{|c|}{$\frac{\text { Risk aversion } \gamma=60}{\text { Shock to: }}$} & \multirow[b]{2}{*}{ Data } \\
\hline & & & & $Y, S$ & $Y$ & $s$ & $Y, s$ & $Y$ & $s$ & $Y, S$ & $Y$ & S & \\
\hline & (1) & (2) & (3) & (4) & (5) & (6) & (7) & (8) & (9) & (10) & (11) & (12) & 3) \\
\hline \multicolumn{14}{|c|}{ Standard deviations (in \%) } \\
\hline $\mathrm{Y}$ & 0.65 & 0.56 & 0.00 & 0.65 & 0.56 & 0.00 & 0.65 & 0.56 & 0.00 & 0.65 & 0.56 & 0.00 & 0.69 \\
\hline C & 0.63 & 0.54 & 0.00 & 0.52 & 0.45 & 0.04 & 0.53 & 0.44 & 0.13 & 0.59 & 0.44 & 0.29 & 0.64 \\
\hline ER & 0.51 & 0.43 & 0.00 & 1.44 & 1.21 & 0.13 & 1.68 & 1.36 & 0.49 & 1.98 & 1.43 & 1.04 & 2.42 \\
\hline $\mathrm{TX}$ & 0.02 & 0.02 & 0.00 & 0.12 & 0.10 & 0.02 & 0.17 & 0.12 & 0.08 & 0.23 & 0.13 & 0.16 & 0.52 \\
\hline JFA & 1.03 & 0.88 & 0.00 & 6.11 & 5.19 & 0.83 & 8.11 & 6.38 & 3.19 & 10.62 & 6.89 & 6.75 & 7.44 \\
\hline \multicolumn{14}{|c|}{ Correlations with domestic output } \\
\hline $\mathrm{C}$ & 0.99 & 0.99 & -- & 0.88 & 0.90 & -- & 0.81 & 0.85 & -- & 0.71 & 0.83 & -- & 0.73 \\
\hline RER & -0.63 & -0.63 & -- & -0.63 & -0.63 & -- & -0.60 & -0.61 & -- & -0.54 & -0.63 & -- & -0.12 \\
\hline IX & -0.64 & -0.63 & -- & 0.60 & 0.61 & -- & 0.54 & 0.63 & -- & 0.43 & 0.61 & -- & 0.36 \\
\hline JFA & 0.48 & 0.48 & -- & -0.45 & -0.46 & -- & -0.41 & -0.46 & -- & -0.33 & -0.45 & -- & 0.16 \\
\hline \multicolumn{14}{|c|}{ Cross-country correlations } \\
\hline $\mathrm{Y}$ & 0.19 & 0.22 & -- & 0.19 & 0.22 & -- & 0.19 & 0.22 & -- & 0.19 & 0.22 & -- & 0.19 \\
\hline $\mathrm{C}$ & 0.27 & 0.30 & -- & 0.89 & 0.90 & -1.00 & 0.83 & 0.97 & -1.00 & 0.49 & 0.99 & -1.00 & 0.30 \\
\hline \multicolumn{14}{|c|}{ Correlation between $C_{H} / C_{F}$ and RER } \\
\hline & -1.00 & -1.00 & -- & -0.91 & -0.99 & 1.00 & -0.14 & -0.99 & 1.00 & 0.39 & -0.99 & 1.00 & 0.15 \\
\hline \multicolumn{14}{|c|}{ Hansen-Jagannathan bound } \\
\hline & 0.004 & 0.004 & 0.00 & 0.05 & 0.02 & .004 & 0.15 & 0.13 & 0.03 & 0.34 & 0.27 & 0.15 & \\
\hline \multicolumn{14}{|c|}{$\begin{array}{l}\text { Notes: Predicted model statistics are reported for a version of the complete markets model that assumes } \\
\text { shocks to the level and the volatility of output. Cols. (1)-(3), (4)-(6), ( } 7)-(9) \text { and (10)-(12) assume risk } \\
\text { aversion of } \gamma=1 / \text { IES }(=0.66), \gamma=10, \gamma=30 \text { and } \gamma=60 \text {, respectively. Cols. labelled 'Y,s' (see Cols. (1),(4),(7) } \\
\text { and (10)) show moments that obtain when Home and Foreign level and volatility shocks are simultaneously } \\
\text { fed into the equilibrium decision rules. Cols. labelled 'Y' show moments that obtain when just output level } \\
\text { shocks are fed into the decision rules (while output volatility is set at its unconditional mean). Cols. labelled } \\
\text { 's' show moments that obtain when just volatility shocks are fed into the decision rules. } \\
\text { Variables are listed in the left-most column. Statistics for output (Y), consumption (C), the real exchange } \\
\text { rate (RER) pertain to log growth rates of these variables. Moments for net exports (NX) pertain to the first } \\
\text { difference of net exports normalized by GDP; moments for net foreign assets (NFA) pertain to annual first } \\
\text { differences of net foreign assets normalized by annual GDP. A rise in RER represents an appreciation. } \\
\text { The Hansen-Jagannathan bound is defined as the ratio of the unconditional standard deviation of the } \\
\text { intertemporal marginal rate of substitution (IMRS), divided by the unconditional mean of the IMRS. } \\
\text { Column (13) shows empirical statistics for the US (from Table 1). }\end{array}$} \\
\hline
\end{tabular}


Table 3. Predicted moments: complete markets model with shocks to output level, output volatility and risk aversion

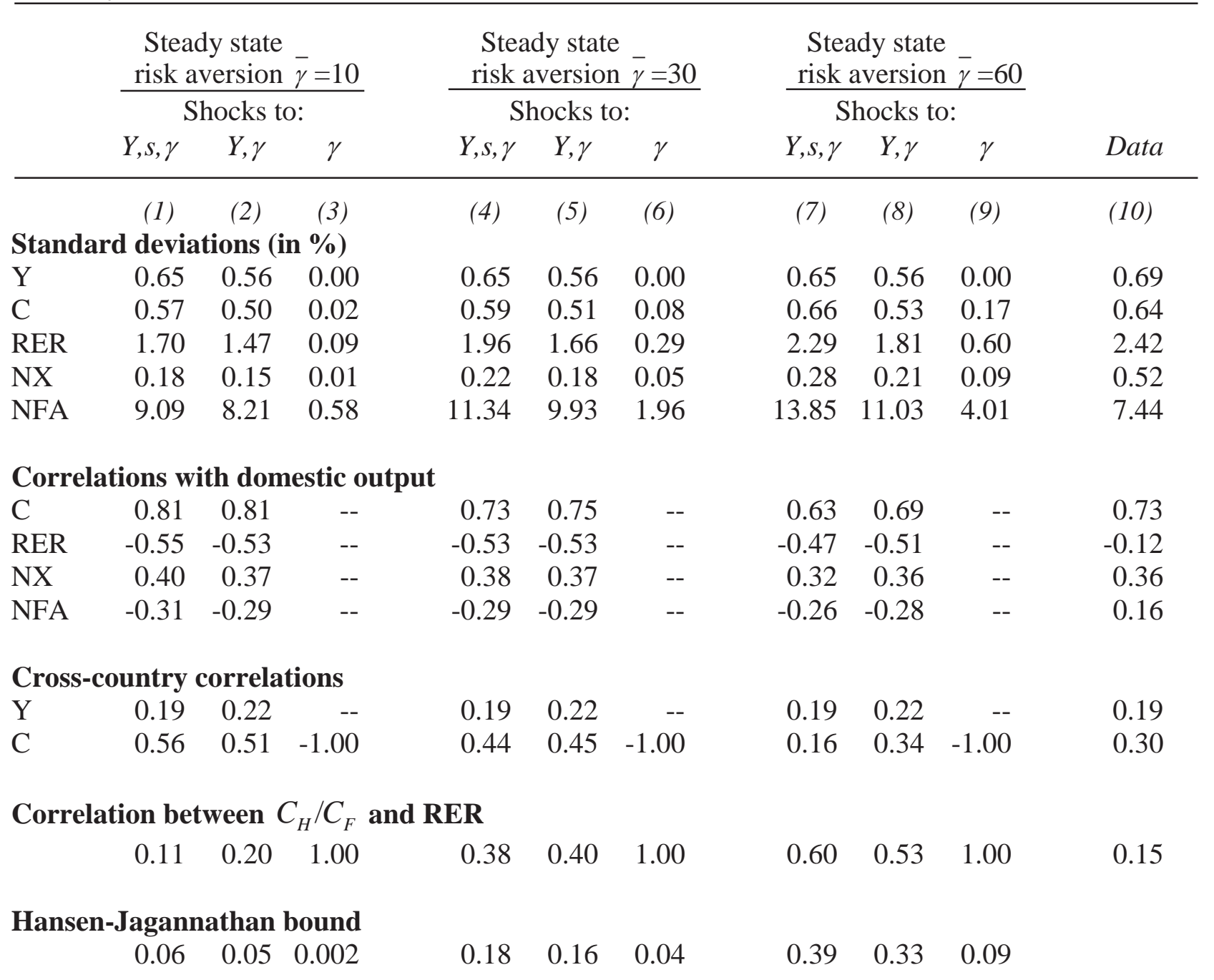

Notes: Predicted model statistics are reported for a version of the complete markets model that assumes shocks to the level and the volatility of output, as well as shocks to Home and Foreign risk aversion coefficients. Cols. (1)-(3), (4)-(6) and (7)-(9) assume steady state risk aversion of 10, 30 and 60, respectively. Cols. labelled ' $Y, s, \gamma$ ' show moments that obtain when Home and Foreign output level, volatility and risk aversion shocks are simultaneously fed into the equilibrium decision rules. Cols. labelled ' $Y, \gamma$ ' show moments that obtain when just level shocks and risk aversion shocks are fed into the decision rules (while output volatility is set at its unconditional mean). Cols. labelled ' $\gamma$ ' show moments that obtain when just risk aversion shocks are fed into the decision rules. See Table 2 for further information. 
Table 4. Predicted moments: bonds-only model with shocks to output level, output volatility and risk aversion (steady state risk aversion: $\bar{\gamma}=30$ )

\begin{tabular}{|c|c|c|c|c|c|c|}
\hline & \multicolumn{5}{|c|}{ Shocks to: } & \multirow[b]{2}{*}{ Data } \\
\hline & $Y, s, \gamma$ & $Y, s$ & $Y, \gamma$ & $S$ & $\gamma$ & \\
\hline & (1) & (2) & (3) & (4) & (5) & (6) \\
\hline \multicolumn{7}{|c|}{ Standard deviations (in \%) } \\
\hline $\mathrm{Y}$ & 0.65 & 0.65 & 0.56 & 0.00 & 0.00 & 0.69 \\
\hline $\mathrm{C}$ & 0.61 & 0.60 & 0.52 & 0.03 & 0.04 & 0.64 \\
\hline RER & 0.68 & 0.66 & 0.56 & 0.13 & 0.16 & 2.42 \\
\hline NX & 0.03 & 0.02 & 0.02 & 0.02 & 0.02 & 0.52 \\
\hline NFA & 0.24 & 0.23 & 0.09 & 0.14 & 0.05 & 7.44 \\
\hline
\end{tabular}

\section{Correlations with domestic output}

$\begin{array}{lrrrrrr}\text { C } & 0.99 & 0.99 & 0.99 & -- & -- & 0.73 \\ \text { RER } & -0.60 & -0.62 & -0.60 & -- & -- & -0.12 \\ \text { NX } & -0.07 & -0.10 & -0.08 & -- & -- & 0.36 \\ \text { NFA } & -0.04 & -0.04 & -0.03 & -- & -- & 0.16\end{array}$

\section{Cross-country correlations}

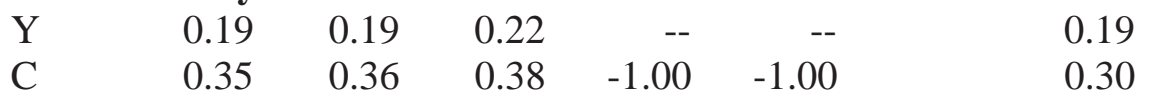

Correlation between $C_{H} / C_{F}$ and RER

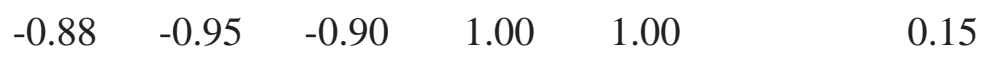

\section{Hansen-Jagannathan bound}

$$
\begin{array}{lllll}
0.27 & 0.18 & 0.25 & 0.06 & 0.04
\end{array}
$$

Notes: Predicted model statistics are reported for a version of the bonds-only model that assumes shocks to the level and the volatility of output, as well as shocks to the risk aversion coefficient. The steady state risk aversion coefficient is set at $\bar{\gamma}=30$. Col. (1) labelled ' $Y, s, \gamma$ ' shows moments that obtain when Home and Foreign output level, volatility and risk aversion shocks are simultaneously fed into the decision rules. Cols. (2)-(5) show predicted moments that obtain when just subsets of the (Home and Foreign) shocks are fed into the decision rules-'Y,s ': just level and volatility shocks; 'Y, $\gamma$ ': level and risk aversion shocks; 's, $\gamma$ ': volatility and risk aversion shocks. See Table 2 for further information. 
Table 5. Dynamic responses to Home country innovations (1 standard deviation)

\begin{tabular}{|c|c|c|c|c|c|c|c|}
\hline Horizon & $Y_{H}$ & $Y_{F}$ & $C_{H}$ & $C_{F}$ & $R E R$ & $N X_{H}$ & $N F A_{H}$ \\
\hline & $(1)$ & (2) & (3) & (4) & (5) & (6) & (7) \\
\hline \multicolumn{8}{|c|}{$\begin{array}{l}\text { (a) Complete markets model; risk aversion } \gamma=\mathbf{1} / \text { IES } \\
\text { Innovation to Home output level }\end{array}$} \\
\hline 0 & 0.56 & 0.00 & 0.53 & 0.03 & -0.34 & -0.02 & 1.39 \\
\hline 4 & 0.56 & 0.00 & 0.53 & 0.03 & -0.34 & -0.02 & 1.39 \\
\hline 20 & 0.55 & 0.01 & 0.52 & 0.04 & -0.33 & -0.02 & 1.35 \\
\hline 40 & 0.54 & 0.02 & 0.52 & 0.04 & -0.32 & -0.02 & 1.31 \\
\hline
\end{tabular}

(b) Complete markets model; steady state risk aversion $\bar{\gamma}=30$. Innovation to Home output level

$\begin{array}{llllllll}0 & 0.56 & 0.00 & 0.32 & 0.24 & -1.11 & 0.10 & -9.91 \\ 4 & 0.56 & 0.00 & 0.32 & 0.24 & -1.11 & 0.10 & -9.89 \\ 20 & 0.55 & 0.01 & 0.31 & 0.25 & -1.09 & 0.10 & -9.79 \\ 40 & 0.54 & 0.02 & 0.31 & 0.25 & -1.06 & 0.10 & -9.66\end{array}$

Innovation to Home output volatility

$\begin{array}{llllllll}0 & 0.00 & 0.00 & 0.10 & -0.10 & 0.34 & -0.05 & 4.44 \\ 4 & 0.00 & 0.00 & 0.09 & -0.09 & 0.31 & -0.05 & 4.04 \\ 20 & 0.00 & 0.00 & 0.06 & -0.06 & 0.21 & -0.03 & 2.60 \\ 40 & 0.00 & 0.00 & 0.03 & -0.03 & 0.11 & -0.02 & 1.10\end{array}$

Innovation to Home risk aversion

$\begin{array}{llllrrrr}0 & 0.00 & 0.00 & 0.05 & -0.05 & 0.19 & -0.03 & 2.44 \\ 4 & 0.00 & 0.00 & 0.01 & -0.01 & 0.06 & -0.01 & 0.61 \\ 20 & 0.00 & 0.00 & -0.04 & 0.04 & -0.14 & 0.02 & -2.23 \\ 40 & 0.00 & 0.00 & -0.05 & 0.05 & -0.18 & 0.03 & -2.77\end{array}$

(c) Bonds-only model; steady state risk aversion $\bar{\gamma}=30$.

Innovation to Home output level

$\begin{array}{lllllllr}0 & 0.56 & 0.00 & 0.51 & 0.05 & -0.43 & -0.003 & -0.002 \\ 4 & 0.56 & 0.00 & 0.51 & 0.05 & -0.43 & -0.003 & -0.01 \\ 20 & 0.55 & 0.01 & 0.50 & 0.06 & -0.42 & -0.002 & -0.06 \\ 40 & 0.54 & 0.02 & 0.49 & 0.07 & -0.41 & -0.001 & -0.11\end{array}$

Innovation to Home output volatility

$\begin{array}{llllllll}0 & 0.00 & 0.00 & -0.02 & 0.02 & -0.09 & 0.01 & 0.01 \\ 4 & 0.00 & 0.00 & -0.02 & 0.02 & -0.08 & 0.01 & 0.07 \\ 20 & 0.00 & 0.00 & -0.02 & 0.02 & -0.06 & 0.01 & 0.26 \\ 40 & 0.00 & 0.00 & -0.01 & 0.01 & -0.03 & 0.00 & 0.47\end{array}$

Innovation to Home risk aversion

$\begin{array}{llllrrrr}0 & 0.00 & 0.00 & -0.03 & 0.03 & -0.11 & 0.02 & 0.02 \\ 4 & 0.00 & 0.00 & -0.02 & 0.02 & -0.07 & 0.01 & 0.07 \\ 20 & 0.00 & 0.00 & -0.00 & 0.00 & -0.00 & 0.00 & 0.15 \\ 40 & 0.00 & 0.00 & 0.00 & -0.00 & 0.01 & -0.00 & 0.17\end{array}$

Note: The Table shows effect of exogenous innovations on the expected values of selected variables after 0,4 and 40 quarters (see left-most Column labeled 'Horizon'). Cols. (1)-(7) show responses of Home and Foreign output and consumption, the Home real exchange rate, Home net exports and of Home net foreign assets. Net exports and net foreign assets are normalized by quarterly Home output. A rise in RER is an appreciation. Responses of output and consumption are expressed as \% deviations from expected unshocked paths. Responses of net exports and net foreign assets (normalized by GDP) are expressed as percentage point differences from unshocked paths. All predetermined state variables are set at their unconditional mean, in the period of the shock $(\mathrm{t}=0)$. 